\title{
Subjectivity in the life and works of Paulo Coelho
}

\author{
${ }^{1}$ Mr. Animesh Sharma, ${ }^{2}$ Dr. Shriya Goyal \\ ${ }^{1}$ Uttaranchal University, Dehradun \\ ${ }^{2}$ Uttaranchal University, Dehradun
}

\section{Introduction}

Be it at any given point of time, humans have had to make their decisions based off their unique set of experiences. When faced with dilemmas, it becomes easier for them to turn to peers or even excerpts from philosophical texts to make decisions in precarious situations. As life becomes more and more complicated, so does a person's understanding of these notions. Meanwhile, shifting base and travelling to be exposed to other cultures broadens horizons which only makes the process of decision- making all the more comprehensive, now that several ideologies are conflicting as well as complementing each other. This is what gives rise to a person's subjectivity, i.e., the concept of a person's decisions being influenced by their tastes, experiences, feeling and opinions. The rise of the notion of subjectivity has its philosophical roots in the thinking of Descartes and Kant(1), and its articulation throughout the modern era has depended on the understanding of what constitutes an individual. The aim of this paper is to unearth the myriad philosophies and beliefs Paulo Coelho encountered in his travels throughout the world and how they influenced his subjectivity which is so well reflected in his works over the years. The paper responds to the question of what role did the $20^{\text {th }}$ century ideologies play in shaping the different phases of his life as well as his books.

Article Received: 18 October 2020, Revised: 3 November 2020, Accepted: 24 December 2020

\section{Discussion}

Paulo Coelho is one of the best-selling and most translated authors of the modern times. He managed to integrate philosophies related to self-consciousness and non-conformity on one end of the spectrum to spirituality on the other.

While it is easy to determine which portion of his expansive body of work was influenced by his then current state of mind, it cannot be denied that his accumulation of knowledge on his many travels and experiences led to a more individualistic expression of the many complicated philosophies.

In the $20^{\text {th }}$ century, Europe was still a hub of knowledge with the concepts of nihilism, existentialism and the individual. Nihilism in essence is a concept that expresses some form of negation towards life. It has been a part of various philosophies but the more contemporary understanding of the idea stems largely from the philosophies of German philosopher Friedrich Nietzsche. Many believe that The statement "God is dead," occurring in several of Nietzsche's works (notably in The Gay Science), is a testament to his absolute rejection of a higher power, but others believe it to be a more subtle understanding of divinity. To put it simply, Nietzsche outlines that nihilism means that nothing has any inherent importance and that life lacks purpose. This came about as scientific developments and the increasing secularization of Europe had effectively 'killed' the God, who had served as the basis for meaning and value as well as the justification for the existence of evil in the West for more than a thousand years. (2)

On the other hand, Jean Paul-Sartre, who is known as the father of Existentialist philosophy, expressed in his famous lecture in Paris, 1945 'Existentialism is a Humanism' (a transcription of his lecture was published in 1946 by the same name) people are free agents who have control over their choices and actions. Moreover, society should not restrict an individual's life or actions and that these restrictions inhibit free will and the development of that person's potential. The term "Existence over essence" became the maxim of the existentialist movement, saying that it is but our choice that makes us who we are and we must be entirely responsible for our own existence in this society.

Building on the philosophies of self, Carl Jung was mentored by Sigmund Freud to take forward his "new science" of psychoanalysis. According to Jungian psychology, individuation is a process of psychological integration. "In general, it is the process by which individual beings are formed and differentiated [from 
other human beings]; in particular, it is the development of the psychological individual as a being distinct from the general, collective psychology."(3)

It is the process of transformation through which the personal and collective unconscious are brought into consciousness (by means of dreams, active imagination, or free association) to be assimilated into the whole personality. He believed it is a completely natural process necessary for the integration of the psyche. Individuation has a holistic healing effect on the person, both mentally and physically. (4)

While Europeans were on the path of finding their individualistic self, Asia was still leaning toward spirituality and religion. Taoism is a religion and a philosophy from ancient China that has had its influence over national belief. Taoism has been connected to the philosopher Lao Tzu, who around 500 B.C.E. wrote the principle book on Taoism, the Tao Te Ching or "The Way and its Power". The tenet dictates that humans and animals should live in balance with the 'Tao', or the universe. Taoists believe in spiritual immortality, where the spirit of the body joins the universe after death. (5)

Similarly, Buddhism was a major influence in Eastern countries, influencing parts of China as well. Even though the religion/ faith has many steps and truths to follow, the main idea relates to the equality of all human beings who have to go through endless suffering but must try to attain 'Nirvana' by giving up material possessions and walk the path of wisdom. (6)

This leads us to the Japanese Zen philosophy, which further inspired Paulo Coelho's move towards spirituality. Zen Buddhism is a simpler, uncompromising, cut-to-the-chase, meditation-based Buddhism that does not necessarily adhere to all doctrines. Not relying on Buddhist scripture, Zen is verified by personal experience and is passed on from master to disciple, hand to hand, ineffably, through hard, intimate training.

Zen Buddhism developed its own set of scriptures, borrowing from prevalent Chinese and Eastern philosophies of the time- Confucianism and Taoism; and is largely anecdotal in nature. Although it began in China, it gained mass popularity in the West in the $20^{\text {th }}$ century. The essence of the faith is that all human beings are Buddha, and all they need to do is to discover that truth for and within themselves. Zen sends them looking inside themselves for

enlightenment and believes that humans can't learn the truth by philosophising or rational thought, nor by studying scriptures, taking part in worship rites and rituals or any other practices that is seen as pertinent to religion. Zen Buddhism teaches people to control their minds through meditation and other techniques that involve mind and body; to not be misled by logical thought or language. (7)

In conclusion, as Paulo Coelho travelled across the globe on his many adventures, he was subconsciously influenced by the various prevalent philosophies. From being a child raised as a staunch Christian, he faced repeated institutionalization for wanting to be a writer only to turn to the occult forces as an escape. This nonconformist, hippie life lasted all through his twenties and thirties till he got to visit countries and experience their tryst with spirituality. He might not have realized it right away but it was the road to Santiago de Compostela that re-ignited the faith in him. He started looking for signs to embark on the journey of his true calling- a writer.

It is this very exposure to diverse prevalent ideologies and their amalgamation in his body of works that resonates with a wider audience base. His experiences and beliefs throughout the years make his characters extremely relatable through ages and boundaries alike.

\section{REFERENCES}

(1) Sethi, J. (2015). Kant on Subjectivity and SelfConsciousness. UC Berkeley., Observations on the Feeling of the Beautiful and Sublime (1764) Book by Immanual Kant

(2) Morgan, George Allen (1941). What Nietzsche Means. Cambridge, MA: Harvard University Press. p. 36. ISBN 978-0-8371-7404-4.

(3) Jung, C.G. Psychological Types. Collected Works, vol. 6, par. 757.

(4) Jung, C.G. (1962). Symbols of Transformation: An Analysis of the Prelude to a Case of Schizophrenia (vol. 2). New York: Harper \& Brothers.

(5) Elizabeth Pollard; Clifford Rosenberg; Robert Tignor (16 December 2014). Worlds Together, Worlds Apart: A History of the 
World - From the Beginnings of Humankind to the Present. W.W. Norton. p. 164. ISBN 978-0-393-91847-2.

(6) THE BUDDHIST CORE VALUES AND PERSPECTIVES FOR PROTECTION CHALLENGES: $\quad$ FAITH AND PROTECTION High Commissioner's Dialogue on Protection Challenges; Theme: Faith and Protection English (12-13 December 2012)

Distr: General

20 November 2012
Original: English

English and French only

(7)https://www.bbc.co.uk/religion/religions/buddhi sm/subdivisions/zen_1.shtml\#: :text= Zen\%20is\%20not\%20a\%20philosophy,Zen\%2 0is\%20meditation.

Author 1: Animesh Sharma Author 2: Dr. Shriya Goyal University: Uttaranchal University, Dehradun 